\title{
Adolescents' Locus of Causality Differences according to Age and Gender as Determined by Communication Locus of Causality Measure
}

\author{
Kyungjae Lee \\ Department of Audiology and Speech-Language Pathology, Daegu Catholic University, Gyeongsan, Korea
}

Correspondence: Kyungjae Lee, $\mathrm{PhD}$ Department of Audiology and Speech-Language Pathology, Daegu Catholic University, 13-13 Hayang-ro, Hayang-eup, Gyeongsan 38430, Korea Tel: $+82-53-850-2543$

Fax: $+82-53-359-6780$

E-mail: kjlee0119@cu.ac.kr

Received: October 2, 2017

Revised: November 19, 2017

Accepted: November 24, 2017

This work was supported by the Ministry of Education of the Republic of Korea and the National Research Foundation of Korea (No. NRF2015S1A5A8017349).

\begin{abstract}
Objectives: A questionnaire-type measure for communication-related locus of causality of adolescents who stutter has been recently proposed. The primary purpose of the current study was to apply this proposed measure and determine whether there would be differences in Communication Locus of Causality scores according to age and gender. Moreover, the validity of the questionnaire-type measure would be determined by comparison with locus of causality scores based on content analysis, Locus of Control of Behavior (LCB) scores, and communication attitude test scores. Methods: $\mathrm{A}$ total of 40 adolescents who do not stutter took part in the current study. They completed the questionnaire-type measure of Communication Locus of Causality measure. In addition, two writing samples of the participants were analyzed following content analysis procedures to produce communicationrelated and general locus of causality scores. The LCB and Communication Attitude Test (Paradise-Fluency Assessment-II) were also administered. Results: There was no significant difference in the Communication Locus of Causality scores and other measures' scores according to age and gender, although there was a medium-sized effect. There were some significant relationships among the measures. Conclusion: The results of the current study suggest that the Communication Locus of Causality measure has appropriate validity. In addition, possible individualized differences of adolescents should be considered in the assessment and management of adolescents who stutter.
\end{abstract}

Keywords: Stuttering, Adolescents, Origin, Pawn, Locus of causality
말더듬은 말의 비유창성, 부수행동, 감정과 태도 등으로 이루어 진 다면적 장애이기에 치료 효과의 측정 역시 다면적으로 이루어져 야 한다(Guitar, 2014; Manning, 2010). 특히 말더듬의 내적 특성 중 통제소(locus of control)의 변화는 치료 후 재발을 예측할 수 있는 요인으로 제시되었으나 통제소는 단선적인 구성요소이기에 말더 듬 치료 중 나타날 수 있는 역동적인 변화를 적절히 나타내지 못할 수 있다는 단점 역시 지적되었다(Craig, Franklin, \& Andrews, 1984; De Nil \& Kroll, 1995; Lee, Manning, \& Herder, 2011, 2015). 이와 관련하여 통제소와 유사한 구성요소인 인과소(locus of causality) 는 오리진과 폰, 두 가지 양상으로 측정되기에 말더듬 치료 중 나타 날 수 있는 개별적인 변화를 민감하게 나타낼 수 있다는 장점이 있 다(Lee et al., 2011, 2015). 인과소(locus of causality)는 자신의 행동
의 원인에 대한 믿음으로 크게 오리진(Origin)과 폰(Pawn)으로 이 루어진다(DeCharms, 1968). 오리진은 스스로 원해서 행동을 하였 다고 믿는 반면, 폰은 스스로 원해서가 아니라 외부의 영향, 혹은 우연 등으로 인하여 행동을 하게 되었다고 믿는다. 이러한 오리진 과 폰은 주로 내용분석을 통하여 측정되었는데, 내용분석은 자유 롭게 작성한 말이나 글의 내용 중 작성자의 오리진 혹은 폰 성향을 나타내는 표현을 분석하는 절차를 제공한다(Lee et al., 2011; Westbrook \& Viney, 1980). 이러한 내용분석의 가장 중요한 가정은 대 상자의 심리적 특성은 대상자가 사용하는 언어에 나타난다는 것이 며, 이에 체계적인 절차를 이용하여 대상자의 언어를 분석하면 대 상자의 특성을 알 수 있다는 것이다(Gottschalk \& Gleser, 1969).

내용분석에 기반하여 말더듬성인의 치료 중 오리진과 폰의 변화 
를 살펴본 결과(Lee et al., 2011, 2015), 말더듬성인은 치료를 받기 시작하였을 때에는 낮은 오리진 점수와 높은 폰 점수를 보였으나 치료 중 오리진 점수의 상승과 폰 점수의 하락을 보였다. 그 결과, 치 료 후에는 높은 오리진 점수와 낮은 폰 점수가 관찰되었다. 또한 인 과소가 오리진과 폰이라는 두 가지 양상으로 측정되기에 대상자의 개별적인 변화 양상 역시 민감하게 나타낼 수 있었다. 예를 들어 다 수의 말더듬치료 참여자가 위와 같은 오리진의 향상과 폰의 감소라 는 바람직한 변화양상을 보였으나 이외에도 오리진의 변화 없이 폰 점수의 감소를 보인 경우, 폰 점수의 변화 없이 오리진 점수의 상승 을 보인 경우 등이 관찰되었다. 더불어 오리진 점수 하락과 폰 점수 상승과 같은 매우 개별적인 변화 양상 역시 관찰되었다. 더불어 일 반성인과 말더듬성인을 비교한 결과, 높은 폰 점수가 말더듬성인의 특징이었다(Lee et al., 2015). 비록 국내 말더듬성인의 치료 중 인과 소 변화와 관련된 연구는 부족하지만 국내 말더듬성인 역시 해외 말더듬성인과 유사한 인과소 패턴을 보였다(Shin, Lee, \& Sung, 2015). 국내 말더듬성인을 대상으로 인과소를 연구한 결과, 이들은 일반성인보다 유의하게 높은 폰 점수를 보였으며 오리진 점수에서 는 유의한 차이가 관찰되지 않았다(Shin et al., 2015). 이러한 결과 는 국내 말더듬성인에게도 내용분석을 이용한 내적 특성의 평가가 적절하며, 높은 폰 점수가 일반적인 말더듬성인의 특징이라는 점을 나타내지만 통제소를 제외한 다른 내적 특성 평가도구와 인과소와 의 상관관계 등을 살펴보지 못하였다는 제한점도 있다.

더불어 내용분석을 이용한 인과소 분석이 말더듬성인의 심리적 특성을 민감하게 나타낸다는 장점이 있으나 글의 내용을 주관적으 로 분석하기에 분석 훈련 및 신뢰도와 관련된 단점이 있을 수 있다 (Lee, 2017). 전술하였듯이 내용분석은 대상자의 말 또는 글을 대상 으로 그 글 자료의 내용이 오리진 혹은 폰을 나타내는지 분석자가 판단을 하여야 한다. 이전 연구에 따르면 분석자는 연습을 통하여 적절한 수준으로 내용분석의 신뢰도를 얻을 수 있었다고 보고하고 있으나 일반적인 임상가가 이를 현장에서 적용하기에는 어려움이 있을 수 있다(Lee et al., 2011; Shin \& Lee, 2014). 더불어 분석 자료 의 길이가 인과소 점수의 보정계수로 사용되기에 분석자는 글의 길 이를 단어 혹은 어절로 측정하여야 하며, 인과소 내용분석의 기본 분석단위는 절(clause)이기에 대상자의 글 자료를 절로 구분하여야 한다. 이러한 글 자료의 언어분석 역시 임상가가 현장에서 적용하 는데 어려움으로 작용할 수 있다(Shin \& Lee, 2014; Westbrook \& Viney, 1980). 이와 관련하여 해외에서는 컴퓨터를 이용한 자동분 석 등이 연구되고 있으나 아직 국내에서는 이와 같은 연구는 부족 한 편이다.

또한 이전 인과소 연구가 주로 일반성인을 대상으로 진행되었다
는 점 역시 제한점이 될 수 있다. 전술하였듯이 내용분석의 주요한 가정 중 하나는 대상자의 심리적 특성이 대상자가 사용하는 언어 에 나타난다는 것이기에 대상자의 언어 사용 능력이 부족한 경우 내용분석이 적절히 사용될 수 없을 수 있다(Gottschalk \& Gleser, 1969). 이에 이전 말더듬 관련 인과소 연구는 주로 언어에 문제가 없는 성인을 대상으로 하였다(Lee et al., 2011, 2015; Shin et al., 2015). 하지만 말더듬의 경우 학령전기부터 시작하여 다양한 연령대에 관 찰이 되며, 특히 청소년의 치료가 어렵다는 점이 강조되었다(Guitar, 2014; Manning, 2010). 이는 청소년이라는 집단 자체의 특이성 뿐 아니라 치료사와 대상자와의 관계, 이전 치료 경험 등이 전체적 으로 치료에 부정적으로 영향을 끼칠 수 있기 때문이다. 하지만 이 시기의 치료는 학교에서의 놀림과 괴롭힘, 이후 성인 시기의 삶의 질에 영향을 끼칠 수 있기에 매우 중요하며, 국내 연구 역시 말더듬 청소년이 적응 등에서 부정적인 모습을 보인 것으로 나타났다(Blood \& Blood, 2004; Hugh-Jones \& Smith, 1999; Lee, Lee, Sim, \& Oh, 2016; McAllister, Collier, \& Shepstone, 2012; O’Brian, Jones, Packman, Menzies, \& Onslow, 2011; Williams, Melrose, \& Woods, 1969). 이에 말더듬청소년의 내적 특성을 적절히 평가하고 이와 같은 결과 를 적용하여 효율적인 치료를 계획하여야하나 내용분석을 이용하 여 이들의 내적 특성을 측정하기에는 어려움이 있을 수 있다. 비록 정상적인 언어발달을 보이는 청소년의 경우, 자신이 의도하는 바를 적절히 표현할 수 있는 언어능력이 있을 수 있으나 청소년이라는 특 성으로 인하여 말더듬청소년이 겪을 수 있는 다양한 학교 및 생활 과 관련된 내용을 이들이 적절히 표현하지 않을 수 있다.

위와 같은 내용분석의 제한점을 보완하고 평가도구가 부족한 말 더듬청소년을 대상으로 하는 설문지 형식의 인과소 평가도구가 제 시되었으나(Lee, 2017) 아직 일반인들과의 비교에는 부족한 점이 있다. Lee (2017)는 7개의 오리진 관련 문항과 7개의 폰 관련 문항 등 총 14 개의 문항으로 이루어진 라이케르트 척도 형식의 "의사소 통 인과소 평가도구(Communication Locus of Causality Measure)" 를 제시하였다. 의사소통 인과소 평가도구는 세 가지 측면에서 결 과를 제시하는데, 우선 오리진 관련 항목들의 합인 오리진 점수, 폰 관련 항목들의 합인 폰 점수, 그리고 오리진 항목의 점수를 역으로 산출한 후 이를 폰 점수와 합산한 총 점수를 계산한다. 자유롭게 작 성된 글 자료를 분석하는 내용분석과 비교, 제한된 항목으로 이루 어진 평가도구가 대상자의 개별적인 특성을 민감하게 나타내기에 는 어려움이 있을 수 있지만 임상에서는 평가와 계산이 상대적으 로 쉽게 이루어질 수 있었다. 또한 오리진 점수, 폰 점수, 그리고 총 점이라는 세 가지 측면에서 지표를 제시하기에 인과소의 다면적인 특성을 의사소통 인과소 평가도구는 나타낼 수 있었다. 비록 소수 
의 청소년을 대상으로 하였지만 이와같은 설문지 형식의 의사소통 인과소 평가도구 결과, 말더듬청소년의 오리진 점수와 폰 점수는 모두 일반청소년보다 유의하게 높은 수준을 보였다. 이와 같은 결 과는 말더듬는 사람의 일반적인 특성인 높은 폰 성향을 설문지 형 식의 평가도구가 잘 나타내었다는 점을 시사한다. 더불어 말더듬청 소년의 높은 오리진 점수는 이들이 모두 실험 당시 치료에 참여하 고 있었기에 나타난 결과로, 이와 같은 대상자의 특성을 평가도구 가 민감하게 나타낼 수 있었다고 연구자는 해석하였다. 하지만 Lee (2017)의 연구는 남자 중·고등학생만을 대상으로 하였으며 연령 등 에 따른 차이를 살펴보지 않았기에 그 결과를 임상적으로 적용하 기에는 어려움이 있었다.

이에 본 연구는 의사소통 인과소 평가도구로 측정한 일반청소년 의 인과소가 성과 연령에 따라서 어떠한 차이가 나타나는지 살펴 보고 이를 통하여 임상에 적용할 수 있는 기초자료를 제공하고자 하였다. 전술하였듯이 청소년이라는 시기는 급속한 발전이 나타나 는 시기이기에 본 연구에서는 중학생집단과 고등학생집단으로 연 령대를 구분하여 이들이 연령대에 따라 의사소통 인과소에서 차이 가 나타나는지 살펴보고자 하였다. 더불어 비록 이전 일반대학생 을 대상으로 한 연구에서 성에 따른 인과소 차이는 통계적으로 유 의하지 않았으나 중간 정도 크기의 효과 크기의 차이를 보이는 경 향성이 관찰되었다(Lee, 2013). 이와 관련하여 일반적으로 말더듬 은 성별에 따라 발생률에서 차이가 나타나며 말더듬여성이 말더듬 남성과는 다른 의사소통태도를 보인다는 연구가 있었다(Silverman, 1980). 이러한 성에 따른 차이는 학령기 아동에게서도 관찰되었다 (De Nil \& Brutten, 1991). 더불어 청소년기에는 성 역활과 관련된 고정관념 등이 성별에 따라 다르게 나타난다(Kim, 2008). 이에 급 속한 발전을 보이는 청소년기에서 연령별, 성별로 일반청소년의 인 과소가 어떠한 발전양상을 보이는지 살펴보고 이를 바탕으로 말더 듬청소년의 효율적인 평가와 중재의 기초자료를 제공하는 것이 본 연구의 주요 목적이다. 더불어 설문지 형식의 의사소통 인과소 평가 도구 이외에도 기존에 사용되었던 내용분석을 이용하여 인과소를 측정하였으며, 이렇게 측정된 인과소가 말더듬평가에서 주로 사용 되는 통제소와 의사소통태도평가 결과와 보이는 상관관계를 측정 하여 의사소통 인과소 평가도구의 타당도를 살펴보고자 하였다.

\section{연구방법}

\section{연구대상}

본 연구에서는 총 40 명의 대구/경북, 서울/경기 지역의 일반청소 년이 참여하였다. 이들은 남자중학생 10 명(평균연령 13.80 세, $\mathrm{SD}=$
1.23 ), 여자중학생 10 명(평균연령 13.20 세, $\mathrm{SD}=1.03$ ), 남자고등학 생 10 명(평균연령 15.9 세, $\mathrm{SD}=1.2$ ), 여자고등학생 10 명이었다(평균 연령 16.00 세, $\mathrm{SD}=.82$ ). 이들은 모두 자기보고에 따르면 말더듬, 말, 언어, 심리, 행동 등의 문제가 없었으며 평가자와의 상호작용 시 이 와 관련된 특이한 문제점이 관찰되지 않았다.

\section{평가도구 및 실험방법}

우선 본 연구는 이전 연구에서 말더듬청소년의 의사소통 인과소 를 평가하는데 사용되었던 의사소통 인과소 평가도구(Lee, 2017) 를 사용하여 참여자의 의사소통 관련 인과소를 측정하였다. 전술 하였듯이 의사소통 인과소 평가도구는 총 14 문항으로 이루어진 평 가도구이다. 총 14 문항 중 7 문항은 오리진과 관련된 내용을 기술하 였고 나머지 7문항은 폰 관련 내용을 기술하였다. 참여자는 각 문 항에 대하여 본인의 생각과 비교하여 매우 아닌지(0점) 아니면 매 우 그런지(5점)를 총 6점 척도의 라이케르트 척도에 표시하였다.

이와 더불어 행동통제소검사(Locus of Control of Behavior, LCB; Craig et al., 1984)를 통하여 일반적인 통제소를 측정하였다. 행동 통제소검사는 6점 척도의 라이케르트 형식의 평가도구이며 총 17 문항으로 이루어졌다. 행동통제소검사의 높은 점수는 외적 통제소 를 나타내며, 말더듬성인과 일반성인을 비교한 결과, 말더듬성인이 통계적으로 더 높은 점수를 보였다(Craig et al., 1984).

의사소통과 관련된 태도는 파라다이스-유창성 검사-II (Paradise-Fluency Assessment-II, P-FA-II; Sim, Shin, \& Lee, 2010)의 의 사소통태도검사를 실시하였다. 의사소통태도검사는 총 30 문항으 로 구성되어 있으며, 대상자가 의사소통에 대해서 어떠한 태도를 가지고 있는지 평가하는 도구이다. 본 연구에는 중학생 이상의 연 령대를 대상으로 하는 의사소통태도검사를 사용하였다. 의사소통 태도검사의 높은 점수는 부정적인 의사소통태도를 나타낸다.

본 연구에서는 또한 이전 연구에서 사용한 내용분석방법을 사 용하여 인과소를 측정하였다(Shin et al., 2015). 내용분석의 대상 이 되는 글 자료를 수집하기 위하여 최근 의사소통 경험과 인생에 서 가장 재미있었던 일에 대하여 각 10 분씩 자유롭게 글쓰기를 하 게 하였다.

연구자는 우선 참여자와 참여자의 부모에게 본 연구의 목적, 실 험 방법 등을 설명하였다. 이후 기관윤리심의위원회가 승인한 동의 서에 자발적으로 서명한 사람만을 대상으로 본 연구를 진행하였 다. 실험은 모두 개별적으로 조용한 장소에서 이루어졌다. 평가는 의사소통 인과소 평가도구, 행동통제소검사, 인과소 측정을 위한 글쓰기, 의사소통태도검사 순으로 이루어졌으며, 글쓰기의 두 가지 주제는 무순으로 제시되었다. 


\section{분석방법}

의사소통 인과소 평가도구는 세 가지 방법으로 분석되었다(Lee, 2017). 우선 오리진 성향을 나타내는 문항의 총점을 더하여 오리진 점수를, 폰 점수의 문항의 점수를 더하여 폰 점수를 산출하였다. 또 한 오리진 성향을 나타내는 문항의 경우 이를 역으로 점수를 산출 한 후 폰 점수와 더하여 의사소통 인과소 평가도구의 총점을 산출 하였다.

행동통제소검사는 총 17 문항으로 이루어졌으며 이 중 다섯 문항 은 내적 통제소를, 12 문항은 외적 통제소를 나타낸다. 내적 통제소 를 나타내는 문항의 경우 이를 역으로 채점하여 이를 다른 문항의 채점점수와 합산하여 행동통제소 점수를 산출하였다(Craig et al., 1984).

글쓰기 자료는 이전 연구에서 사용한 방식을 사용하여 의사소 통 관련 인과소 점수와 일반적인 인과소 점수를 산출하였다(Shin et al., 2015). 우선 최근 의사소통 관련 경험의 글 자료에서 각각의 절이 참여자의 오리진 성향 혹은 폰 성향을 직접적으로 나타내는 지 분석한 후 이러한 오리진 절 수와 폰 절 수, 글쓰기 자료의 길이 등을 이용하여 의사소통 관련 오리진 점수와 폰 점수를 산출하였 다. 또한 인생에서 가장 재밌었던 일의 내용 역시 위와 같은 방식으 로 분석하여 일반적인 오리진 점수와 폰 점수를 산출하였다. 또한 각각의 상황에서의 오리진 점수를 폰 점수로 나눈 후 100 을 곱하여 의사소통 관련 오리진-폰 점수비율과 일반적인 오리진-폰 점수 비 율을 산출하였다.

마지막으로 P-FA-II의 의사소통태도검사는 검사지침서에서 제 공하듯이 말더듬는 사람이 반응하는 것과 같은 양식으로 반응한 경우 1점을 부여하여 총점을 산출하였다(Sim et al., 2010).

\section{신뢰도 및 통계분석방법}

총 참여자 40 명 중 10 명 $(25 \%)$ 의 글 자료를 대상으로 내용분석과 관련된 평가자 간 신뢰도를 분석하였다. 독립된 분석가는 언어재활 사 2 급 자격증을 소지한 언어치료 관련 박사과정 학생이었다. 본 연 구의 저자와 독립된 분석가의 평가자 간 신뢰도를 코헨의 카파로 측정한 결과 오리진의 경우. 797 , 폰은 .768 의 일치도를 보였다.

우선 의사소통 인과소 평가도구의 오리진 점수, 폰 점수, 총점수, 행동통제소검사 점수, 의사소통태도검사 점수 등이 대상자의 연령 집단(중학생집단과 고등학생집단)과 성별에 따라 차이가 나타나는 지 이원분산분석(two-way ANOVA)을 사용하여 분석하였다.

또한 의사소통 관련 글쓰기 자료를 이용하여 산출한 의사소통 관 련 오리진 점수와 폰 점수, 오리진-폰 점수 비율, 일반적인 내용의 글 쓰기 자료를 분석하여 산출한 오리진 점수와 폰 점수, 오리진-폰 점
수 비율이 대상자의 연령집단(중학생집단과 고등학생집단), 성별, 상 황(의사소통과 일반적인 상황)에 따라 차이가 나타나는지는 반복 분산측정(repeated measure of ANOVA)을 사용하여 분석하였다.

더불어 성과 나이에 따른 차이의 효과크기는 Cohen's $d$ 로 측정 하였는데 이는 집단에 따른 차이를 임상적으로 살펴보기 위함이었 다. 더불어 의사소통 인과소 평가도구, 내용분석을 통한 인과소 결 과, 행동통제소검사, 의사소통태도검사 등의 결과의 상관관계를 피 어슨 상관계수 $r$ 을 사용하여 분석하였다.

\section{연구결과}

\section{의사소통 인과소 평가도구 결과}

본 연구 참여자의 의사소통 인과소 평가도구 오리진 점수와 폰 점수, 그리고 총점, 글쓰기 내용을 내용분석도구인 오리진-폰 분석 도구를 사용하여 산출한 의사소통 관련 오리진 점수와 폰 점수, 그 리고 오리진-폰 점수비율, 일반적인 상황에서의 오리진 점수와 폰 점수, 오리진-폰 점수비율, 행동통제소검사 점수, P-FA-II 의사소통 태도검사 점수는 Table 1과 같다.

의사소통 인과소 평가도구의 폰 점수의 경우, 남자중학생은 평 균 7.8점 $(\mathrm{SD}=7.2)$, 여자중학생은 평균 7.0점 $(\mathrm{SD}=5.3)$, 남자고등학 생은 평균 8.2점 $(\mathrm{SD}=5.6)$, 여자고등학생은 평균 10.3 점 $(\mathrm{SD}=5.1)$ 이 었으며 이와 같은 점수는 성(Cohen's $d=.1$ )과 연령(Cohen's $d=.3$ ) 에 따른 차이가 통계적으로 유의하지 않았다( $p>.05)$. 성과 연령의 상호작용 역시 통계적으로 유의하지 않았다( $p>.05)$.

의사소통 인과소 평가도구의 오리진 점수의 경우, 남자중학생은 평균 24.8점 $(\mathrm{SD}=8.1)$, 여자중학생은 평균 23.2 점 $(\mathrm{SD}=4.5)$, 남자고 등학생은 평균 25.1 점 $(\mathrm{SD}=5.6)$, 여자고등학생은 평균 22.2점 $(\mathrm{SD}=4.1)$ 이었으며 이와같은 점수는 성(Cohen's $d=.4)$ 과 연령(Cohen's $d=.06$ ) 에 따른 차이가 통계적으로 유의하지 않았다( $p>.05)$.

오리진 점수를 역으로 계산한 의사소통 인과소 평가도구의 총점 은 남자중학생은 평균 18.0 점( $\mathrm{SD}=11.8)$, 여자중학생은 평균 18.8 점 $(\mathrm{SD}=7.1)$, 남자고등학생은 평균 18.1점 $(\mathrm{SD}=6.8)$, 여자고등학생 은 평균 23.1점 $(\mathrm{SD}=7.2)$ 이었으며 이와 같은 점수는 성(Cohen's $d=$ .34)과 연령(Cohen's $d=.26)$ 에 따른 차이가 통계적으로 유의하지 않았다 $(p>.05)$. 성과 연령의 상호작용 역시 통계적으로 유의하지 않았다 $(p>.05)$.

\section{인과소와 다른 평가도구 결과}

내용분석을 통하여 산출한 의사소통 인과소와 일반적인 인과 소가 성, 나이, 상황에 따라 유의한 차이가 있는지 반복측정분산분 
Table 1. Scores of Communication Locus of Causality, Origin and Pawn Scales, Locus of Control of Behavior, and P-FA-II Communication Attitude Test of adolescents

\begin{tabular}{|c|c|c|c|c|}
\hline \multirow{2}{*}{ Measures } & \multicolumn{2}{|c|}{ Middle school students } & \multicolumn{2}{|c|}{ High school students } \\
\hline & Male & Female & Male & Female \\
\hline \multicolumn{5}{|l|}{ Communication Locus of Causality } \\
\hline Origin scores & $24.8(8.1)$ & $23.2(4.5)$ & $25.1(5.6)$ & $22.2(3.8)$ \\
\hline Pawn scores & $7.8(7.2)$ & $7.0(5.3)$ & $8.2(5.3)$ & $10.3(5.1)$ \\
\hline Total scores & $18.0(11.8)$ & $18.8(7.1)$ & $18.1(6.8)$ & $23.1(7.2)$ \\
\hline \multicolumn{5}{|l|}{ Origin and Pawn Scales } \\
\hline Communication-related Origin scores & $2.6(1.3)$ & $2.3(0.8)$ & $1.9(1.4)$ & $2.0(1.1)$ \\
\hline Communication-related Pawn scores & $2.5(1.3)$ & $2.3(0.8)$ & $2.4(1.2)$ & $2.5(1.2)$ \\
\hline Communication-related Origin-Pawn scores ratio & $106.0(29.1)$ & $108.8(49.1)$ & 78.7 (32.9) & $81.7(42.3)$ \\
\hline General Origin scores & $2.3(1.5)$ & $1.9(.8)$ & $1.7(.8)$ & $2.3(1.2)$ \\
\hline General Pawn scores & $2.7(1.3)$ & $1.7(.6)$ & $2.2(.8)$ & $2.4(1.4)$ \\
\hline General Origin-Pawn scores ratio & $86.3(38.9)$ & $134.3(81.4)$ & $78.4(23.8)$ & $106.8(41.0)$ \\
\hline Locus of Control of Behavior & $34.0(6.6)$ & $31.5(11.0)$ & $34.9(7.4)$ & $34.3(4.6)$ \\
\hline P-FA-II Communication Attitude Test & $6.5(2.5)$ & $6.3(4.1)$ & $9.0(3.1)$ & $8.0(4.9)$ \\
\hline
\end{tabular}

Values are presented as mean (SD).

P-FA-II=Paradise-Fluency Assessment-II (Sim, Shin, \& Lee, 2010).

석을 통하여 살펴보았다. 우선 오리진 점수의 경우 상황, 성, 나이에 따른 주효과는 통계적으로 유의하지 않았다( $p>.05)$. 의사소통 관 련 오리진 점수의 성에 따른 효과크기(Cohen's $d$ )는 .09, 나이에 다 른 효과크기(Cohen's $d$ )는 .45였다. 일반적인 오리진 점수의 성에 따른 효과크기(Cohen's $d$ )는 .11, 나이에 따른 효과크기(Cohen's $d$ ) 는 .14였다. 또한 성과 나이, 성과 상황, 나이와 상황의 상호작용, 성, 나이, 상황의 상호작용 모두 통계적으로 유의하지 않았다 $(p>.05)$.

폰 점수 역시 상황, 성, 나이에 따른 주효과는 통계적으로 유의하 지 않았다( $p>.05)$. 의사소통 관련 폰 점수의 성에 따른 효과크기 (Cohen's $d$ )는 .06, 나이에 따른 효과크기(Cohen's $d$ )는 .03였다. 일 반적인 폰 점수의 성에 따른 효과크기(Cohen's $d$ )는 .34 , 나이에 따 른 효과크기(Cohen's $d$ )는 .08이었다. 또한 성과 나이, 성과 상황, 나 이와 상황의 상호작용, 성, 나이, 상황의 상호작용 모두 통계적으로 유의하지 않았다 $(p>.05)$.

오리진-폰 점수 비율 역시 상황, 성, 나이에 따른 주효과, 성과 나 이, 성과 상황, 나이와 상황의 상호작용, 성, 나이, 상황의 상호작용 모두 통계적으로 유의하지 않았다 $(p>.05)$. 의사소통 관련 오리진폰 점수비율의 성에 따른 효과크기(Cohen's $d$ )는 .1 , 나이에 따른 효과크기(Cohen's $d$ )는 .63이었다. 일반적인 오리진-폰 점수비율의 성에 따른 효과크기(Cohen's $d$ )는 .51, 나이에 따른 효과크기(Cohen's $d$ )는 .74이었다.

더불어 행동통제소검사 결과는 성별(Cohen's $d=.19)$, 연령(Cohen's $d=.22)$ 에 따른 차이가 통계적으로 유의하지 않았다 $(p>.05)$. 성별과 연령의 상호작용 역시 통계적으로 유의하지 않았다( $p>.05)$.
Table 2. Significant correlations among Communication Locus of Causality measure scores and other measures of stuttering

\begin{tabular}{lcc}
\hline \multirow{2}{*}{ Communication Locus of Causality } & \multicolumn{2}{c}{ Significant correlations } \\
\cline { 2 - 3 } & $r$ & $p$-value \\
\hline Origin scores & & \\
$\quad$ Total scores of Communication Locus of Causality & -.734 & $<.001$ \\
Pawn scores & & \\
Locus of Control of Behavior & .496 & .001 \\
P-FA-II Communication Attitude Test scores & .466 & .002 \\
Total scores of Communication Locus of Causality & .745 & $<.001$ \\
Communication-related Pawn scores & .328 & .039 \\
General Origin scores & .385 & .014 \\
\hline
\end{tabular}

P-FA-II = Paradise-Fluency Assessment-II (Sim, Shin, \& Lee, 2010).

의사소통태도검사 점수 역시 성별(Cohen's $d=.16)$ 과 연령(Cohen's $d=.57)$ 에 따른 차이가 통계적으로 유의하지 않았다( $p>.05)$. 성별 과 연령의 상호작용 역시 통계적으로 유의하지 않았다( $p>.05)$.

\section{의사소통 인과소 평가도구와 다른 도구와의 상관관계}

본 연구에서 관찰된 의사소통 인과소 평가도구와 다른 평가도구 와의 유의한 상관관계는 Table 2 와 같다. 우선 의사소통 인과소 평 가도구의 폰 점수는 행동통제소검사 $(r=.496, p=.001)$ 와 의사소통 태도검사 $(r=.466, p=.002)$, 의사소통 인과소 평가도구의 총점 $(r=$ $.745, p<.001)$, 내용분석을 통하여 산출한 의사소통 관련 폰 점수 $(r=.328, p=.039)$, 내용분석을 통하여 산출한 일반적인 상황에서 의 오리진 점수 $(r=.385, p=.014)$ 등과 유의한 상관관계를 보였다. 
의사소통 인과소 평가도구의 오리진 점수는 평가도구의 총점 $(r=-.734, p<.001)$ 과 유의한 상관관계를 보였다.

내용분석을 통하여 산출한 의사소통 관련 오리진 점수는 내용 분석을 통하여 산출한 의사소통 관련 폰 점수 $(r=.762, p<.001)$, 일 반적인상황에서의 오리진 점수 $(r=.706, p<.001)$ 와 폰 점수 $(r=.569$, $p<.001)$, 의사소통 관련 오리진-폰 점수 비율 $(r=.428, p=.006)$ 등 과 유의한 상관관계를 보였다.

내용분석을 통하여 산출한 의사소통 관련 폰 점수는 일반적인 오리진 점수 $(r=.683, p<.001)$, 폰 점수 $(r=.596, p<.001)$ 와 유의한 상관관계를 보였다.

일반적인 상황에서의 오리진 점수는 일반적인 상황에서의 폰 점 수 $(r=.654, p<.001)$ 와 일반적인 상황에서의 오리진-폰 점수비율 $(r=.369, p=.001)$ 과 유의한 상관관계를 보였다. 일반적인 상황에서 의 폰 점수는 일반적인 상황에서의 오리진-폰 점수비율과 유의한 상관관계를 보였다 $(r=-.367, p=.020)$.

행동통제소검사 점수는 의사소통태도 점수와 유의한 양적 상관 관계 $(r=.655, p<.001)$ 를 보였다.

\section{논의 및 결론}

본 연구의 주요 목적은 설문지 형식의 평가도구인 의사소통 인 과소 평가도구를 사용하여 일반청소년의 의사소통 관련 인과소를 측정하고, 이렇게 측정된 일반청소년의 인과소가 성별과 나이에 따 라서 차이가 나타나는지 살펴보는 것이었다. 그 결과, 의사소통 인 과소의 오리진 점수와 폰 점수, 그리고 총점은 성별과 나이에 따른 차이가 통계적으로 유의하지 않았으나 효과 크기가 중간 정도로 나타나는 경향이 관찰되었다. 이와 관련된 논의는 다음과 같다.

\section{성과 연령에 따른 의사소통 인과소 차이}

본 연구 결과, 의사소통 인과소 평가도구로 측정한 일반청소년의 인과소는 성과 연령에 따라 유의한 차이를 보이지 않았다. 하지만 그 효과크기는 중간 정도로 나타났기에 이러한 점을 고려하여 말 더듬청소년의 평가와 치료를 계획하여야 할 것이다. 본 연구에서 중간 정도 크기의 효과크기를 보인 경우를 구체적으로 살펴보면 우선 고등학생이 중학생에 비해 높은 폰 점수(Cohen's $d=.3$ )를, 남 학생이 여학생에 비해 높은 오리진 점수를 보였다(Cohen's $d=.4$ ). 또한 오리진 점수를 역으로 계산한 의사소통 인과소 평가도구 총 점의 경우 여학생이 남학생보다(Cohen's $d=.34$ ), 그리고 중학생보 다 고등학생(Cohen's $d=.26$ )이 높은 총점을 보였다. 우선 이처럼 통계적으로 유의하지 않지만 중간 정도의 효과크기가 나타난 이유
로는 본 연구의 참여자 수가 적었으나 대상자의 변이성이 컸을 가 능성이 있다. 본 연구에서는 남자중학생 10 명, 여자중학생 10 명, 남 자고등학생 10 명, 여자고등학생 10 명 등 총 40 명의 학생이 참여하였 다. 비록 전체 인원수로는 적은 편은 아니지만 각 셀당 참여자 수는 상대적으로 적은 편이었으며, 이들의 거주지는 대구, 경북, 서울, 경 기 등 다양하였으며 셀당 참여자의 거주지가 통제되지 않았다. 이 와 같은 지역적 차이로 인한 변이성도 있었을 가능성이 있기에 이 후 연구에서는 이와 관련된 통제가 필요할 것이다.

위와 같은 본 연구 참여자의 특성적인 제한점으로 인하여 본 연 구는 이전 말더듬청소년 연구와 유사하지만 다른 결과를 나타내었 을 것으로 생각된다. 예를 들어서 본 연구참여자의 의사소통 인과 소 평가도구의 폰 점수는 Lee (2017)가 보고한 일반청소년과 유사 한 수준(평균 7.3점)으로 말더듬청소년(평균 16.7점)보다 매우 낮은 수준이었다. 이와 같은 결과는 의사소통 관련 높은 폰 점수가 말더 듬는 사람의 일반적인 특성이라는 점을 다시 한번 강조한다. 하지 만 의사소통 인과소 평가도구의 오리진 점수의 경우, Lee (2017)의 연구에서는 말더듬청소년이 일반청소년보다 높은 수준을 보였는 데, 본 연구의 참여자들은 이전 연구의 말더듬청소년보다 전반적 으로 높은 수준을 보였다. 이와 같은 말더듬청소년의 높은 오리진 점수를 Lee (2017)는 이들이 모두 치료를 받았기 때문이라고 해석 하였다. 이와 관련하여 본 연구의 결과를 일반화하기에는 참여자 특성과 관련된 제한점이 따를 수 있기에 추가적으로 보다 많은 수 의 통제된 집단의 참여자를 대상으로 한 후속연구가 필요할 것으 로 생각된다. 특히 후속연구에서는 성적, 교우관계, 가족관계 등 인 과소에 영향을 줄 수 있는 보다 다양한 요인들을 통제하여 연구를 실시할 필요가 있을 것이다.

\section{내용분석을 통한 인과소 분석}

자유롭게 작성한 글 자료를 내용분석하여 의사소통 관련 인과 소와 일반적인 상황에서의 인과소를 측정한 결과, 앞서 제시한 설 문지 형식의 의사소통 인과소 평가도구 결과와 같이 성과 연령에 따른 차이는 통계적으로 유의하지 않았다. 또한 중간 정도 크기의 효과크기가 나타난 경우도 있었으나 그 양상은 의사소통 인과소 평가도구의 결과와는 다른 양상이었다. 예를 들어 내용분석을 통 하여 산출한 의사소통 관련 인과소의 오리진 점수의 경우 중학생 이 고등학생보다 높은 경향성(Cohen's $d=.45$ )을 보였으나 설문지 형식의 의사소통 인과소 평가도구의 경우 나이에 따른 효과크기는 작은 편이었다. 또한 내용분석을 통하여 산출한 의사소통 관련 폰 점수는 나이와 성별에 따른 효과크기가 모두 작은 편이었으나 설문 지 형식의 의사소통 인과소 평가도구의 경우 전술하였듯이 나이에 
따른 차이가 중간 정도의 크기였다.

이와 같은 다른 양상은 평가방식의 차이인 것으로 생각된다. 본 연구에서 사용한 의사소통 관련 인과소 내용분석의 경우, 최근 의 사소통 경험이라는 주제만 주어졌을 뿐 참여자는 내용과 형식 등 에 있어서 자유롭게 글을 작성하였다. 반면 설문지 형식의 의사소 통 인과소 평가도구의 경우 비록 상대적으로 소수의 문항으로 구 성되어 있기는 하지만 오리진 관련 항목과 폰 관련 항목의 수는 동 일하였다. 전술하였듯이 의사소통에서의 높은 폰 성향은 말더듬성 인과 청소년의 특징으로 일반성인과 청소년의 경우에는 상대적으 로 높지 않았다. 이에 일반청소년이 자유롭게 글 작성을 할 때에는 절대적으로 폰 관련 기술이 적기에 이러한 내용을 바탕으로 내용 분석을 한 결과에서 성별 혹은 연령에 따른 차이가 상대적으로 적 은 반면 설문지 형식의 평가도구에서는 모든 참여자가 폰과 관련된 항목에 답을 하여야 했다. 이에 설문지 형식의 조사에서 일반청소 년의 나이에 따른 차이가 상대적으로 크게 나타난 것으로 추측된 다. 이에 이후 말더듬청소년과 일반청소년을 대상으로 폰 성향을 절대적으로 비교하기 위해서는 내용분석뿐 아니라 설문지 형식의 의사소통 인과소 평가도구를 함께 사용하는 것이 적절할 것으로 생각된다.

반면 일반적인 폰 점수의 경우에는 남학생이 여학생보다 높은 경향성(Cohen's $d=.34)$ 을 보였는데, 이를 일반대학생을 대상으로 한 연구와 비교하면 다음과 같다. 말을 더듬지 않는 일반대학생을 대상으로 성과 주제에 따른 인과소 차이를 살펴본 결과, 성과 주제 에 따른 인과소 차이는 통계적으로 유의하지 않았다(Lee, 2013). 하 지만 의사소통 관련 오리진 점수의 경우 성에 따른 효과크기(Cohen's $d$ )는 .3, 일반적인 상황에서의 오리진 점수의 경우 성에 따른 효과크기(Cohen's $d$ )는 .68로 남성이 상대적으로 높은 경향성을 보 였다. 반면 의사소통 관련 폰 점수의 경우 성에 다른 효과크기(Cohen's $d$ )는 .98 , 일반적인 상황에서의 폰 점수의 성에 다른 효과크기 (Cohen's $d$ )는 .1이었으며 오리진 점수와 마찬가지로 남성이 여성보 다 높은 경향성을 보였다. 즉 이러한 점을 고려한다면 인과소와 같 은 내적특성의 경우, 남녀가 연령대에 따라 다른 양상을 보일 가능 성을 예상할 수 있다. 이와 관련하여 해외 연구에서는 학령기 말더 듬아동과 성인의 의사소통태도 등에서는 성에 따른 차이가 유의 할 수 있으나 학령전기 말더듬아동에게서는 이와 같은 성에 따른 차이가 유의하지 않았다(De Nil \& Brutten, 1991; Silverman, 1980; Vanryckeghem, Brutten, \& Hernandez, 2005). 이에 국내 말더듬아 동, 청소년, 성인을 대상으로 인과소와 같은 내적 특성이 성별에 따 라 차이가 나타나는지와 관련된, 즉 말더듬의 전 생애적 조망과 관 련된 후속 연구가 필요하다. 이를 통하여 보다 개별적인 말더듬평
가와 중재가 가능할 것이다.

\section{기타 평가도구의 성과 연령에 따른 차이}

본 연구에서 측정한 행동통제소 검사와 P-FA-II 의사소통태도 검사의 경우 성과 연령에 따른 차이가 통계적으로 유의하지 않았으 며, 효과크기 역시 작은 편이었다. 본 연구에서 제시된 행동통제소 검사 점수와 의사소통태도검사 점수는 이전 말더듬청소년과 일반 청소년을 대상으로 한 연구에서의 일반청소년과 유사한 결과를 보 였다. 반면 본 연구에서 관찰된 효과크기 역시 작은 편이었는데, 이 와 같은 점은 의사소통태도의 경우 성과 연령에 따른 차이가 적다 는 점을 나타낸다. 비록 P-FA-II는 중학생 이상의 성인을 하나의 집 단으로 구성하기에 일반 청소년집단의 의사소통태도 점수를 살펴 볼 수 없었으나 본 연구참여자의 평균은 말더듬청소년과 성인을 대 상으로 측정한 백분위점수에서 $10 \%$ ile에 해당하는 점수인 11.1점 보다 낮은 수준이었다. 즉 이와 같은 결과는 의사소통태도가 말더 듬청소년과 일반청소년을 구분할 수 있는 매우 중요한 요인이라는 점을 강조한다.

\section{일반청소년을 대상으로 한 의사소통 인과소 평가도구의 타당성}

본 연구에서 사용한 의사소통 인과소 평가도구의 폰 점수는 오 리진 점수와 비교, 보다 많은 다른 평가도구와 유의한 상관관계를 나타내었는데, 이는 전반적인 의사소통 인과소 평가도구, 특히 폰 점수의 타당성이 높다는 점을 나타낸다. 예를 들어 의사소통 인과 소 평가도구의 폰 점수는 행동통제소검사, 의사소통태도검사와 유 의한 정적 상관관계를 보였다. 이러한 유의한 상관관계는 말더듬청 소년을 대상으로 한 이전 연구와 같은 결과이다(Lee, 2017). 즉 말더 듬청소년과 일반청소년 모두 의사소통 인과소의 폰 점수는 행동통 제소, 의사소통태도와 유의한 상관관계를 보였으며, 이는 의사소 통 인과소 평가도구의 타당성을 나타내는 것으로 해석할 수 있다. 비록 인과소, 행동통제소, 의사소통태도 등이 서로 다른 구성요소 라 할지라도 이러한 구성요소는 모두 말더듬성인의 내적 특성을 나타내는 주요한 특성일 수 있기에 본 연구에서 관찰된 의사소통 인과소 평가도구와 다른 내적 평가도구와의 유의한 상관관계는 의 사소통 인과소 평가도구가 말더듬청소년의 내적 특성을 평가하는 데 적절한 평가도구라는 점을 나타낸다.

더불어 설문지 형식의 의사소통 인과소 평가도구와 내용분석을 이용한 인과소 평가도구와의 상관관계의 정도는 상대적으로 약한 편이었는데 이는 청소년이라는 참가자의 특성과 평가방식의 차이 에 의한 것으로 추측된다. 전술하였듯이 내용분석의 경우 참여자 
는 자유롭게 글을 작성하며, 이렇게 자유롭게 작성된 글의 내용을 분석하여 오리진과 폰 성향을 측정한다. 반면 설문지 형식의 의사 소통 인과소 평가도구는 청소년의 일상생활 속에서 의사소통 인과 소 특성이 잘 나타날 수 있는 상황과 관련된 문항으로 구성되어 있 다. 이와 관련하여 내용분석의 가정 중 하나는 대상자가 자신의 생 각을 자유롭게 글로 나타낼 수 있어야 한다는 점이다. 하지만 청소 년의 경우, 청소년이라는 특성으로 인하여 자신의 생각을 자유롭 게 작성하지 않았을 가능성이 있다. 이에 내용분석을 이용하여 측 정한 인과소와 설문지 형식의 인과소 평가도구 사이에 유의한 상 관관계가 관찰되었으나 그 정도는 상대적으로 낮았을 가능성이 있 다. 반면 설문지 형식의 내적 특성의 평가도구인 의사소통 인과소 평가도구, 행동통제소검사, P-FA-II 의사소통태도검사 사이에는 상대적으로 높은 상관관계가 관찰되었을 수 있다.

반면 의외의 상관관계도 관찰되었는데, 대표적인 것으로는 내용 분석을 통하여 산출한 의사소통 관련 폰 점수와 내용분석을 통하 여 산출한 일반적인 상황에서의 오리진 점수, 내용분석을 통하여 산출한 의사소통 관련 오리진 점수와 의사소통 관련 폰 점수, 일반 적인 상황에서의 폰 점수 등이다. 이와 같은 결과는 내적 통제소와 외적 통제소 사이에 부적 상관관계를 갖는 통제소와는 달리 오리 진과 폰은 그 둘 사이에 부적 상관관계를 갖지 않는 이원적인 개념 이라는 점을 다시 한번 강조한다. 또한 이러한 결과는 내용분석의 점수 변환과정과 관련있을 수 있다. 내용분석을 통한 인과소 측정 방식은 글 자료에서 오리진 혹은 폰을 직접적으로 나타낸 절 수에 .5 를 더한 후 글 자료의 길이를 보정계수로 사용하여 점수를 보정한 다(Westbrook \& Viney, 1980). 즉 오리진이나 폰을 나타내는 절이 없더라도 점수를 받을 수 있는데, 이는 이러한 자료가 많을 경우에 나타날 수 있는 점수분포의 왜도를 보정하기 위함이었다. 또한 글 자료의 길이를 보정계수로 사용하는 이유는 길이가 긴 글은 오리진 이나 폰으로 판단될 수 있는 절의 수가 많을 수 있기 때문이었다. 이 에 오리진 혹은 폰으로 분석되는 절이 없는 경우에도 오리진 점수 와 폰 점수는 동일한 점수로 분석이 되며, 그리고 길이가 짧을수록 보정계수의 영향으로 그 점수는 높을 가능성이 있다. 즉 이렇듯 오 리진과 폰을 직접적으로 나타내는 표현이 없는 자료가 많을수록 오리진과 폰의 상관관계가 높아졌을 가능성이 있다. 이와 관련하 여 내용분석에 있어서 오리진과 폰으로만 분석하는 것이 아니라 오 리진과 폰으로 분석되지 않는, 즉 중립적인 절의 수가 말더듬성인 의 치료에서 중요한 지표일 가능성이 제시되었다(Lee et al., 2015). 이는 의사소통을 자연스러운 것으로 받아들일수록 인과소의 개념 이 직접적으로 글에서 나타나지 않고 중립적으로 의사소통과 관련 된 경험을 기술하리라는 가정을 포함하고 있다. 이에 오리진과 폰
점수뿐 아니라 중립적인 절에 기반을 둔 점수가 말더듬는 사람과 일반인 사이에 어떠한 차이가 나타나는지, 그리고 치료를 통하여 이러한 변화가 관찰되는지 살펴보는 후속 연구가 필요할 것이다.

\section{결론}

일반청소년을 대상으로 제한된 항목으로 이루어진 설문지 형식 의 평가도구인 의사소통 인과소 평가도구로 의사소통과 관련된 인 과소를 측정한 결과, 성과 연령에 따른 차이가 통계적으로 유의하 지는 않았으나 중간 정도의 효과크기를 보였다. 더불어 설문지 형 식의 평가도구로 측정한 인과소 점수는 내용분석을 이용하여 측 정한 인과소 점수뿐 아니라 다른 내적 특성과 관련된 도구와도 유 의한 상관관계를 보였다. 이러한 결과는 설문지 형식의 의사소통 인과소 평가도구가 말더듬청소년의 주요한 특성일 수 있는 인과소 를 타당하고 민감하게 나타낼 수 있다는 점을 시사한다. 하지만 상 대적으로 적은 수의 참여자를 대상으로 본 연구는 진행되었기에 후속 연구에서는 보다 다양한 다수의 참여자를 대상으로 한 말더 듬청소년과 일반청소년의 직접적인 비교연구가 필요할 것이다.

\section{REFERENCES}

Blood, G. W., \& Blood, I. M. (2004). Bullying in adolescents who stutter: communicative competence and self-esteem. Contemporary Issues in Communication Science and Disorders, 31, 69-79.

Craig, A., Franklin, J., \& Andrews, G. (1984). A scale to measure locus of control of behavior. British Journal of Medical Psychology, 57, 173-180.

De Nil, L. F., \& Brutten, G. J. (1991). Speech-associated attitudes of stuttering and nonstuttering children. Journal of Speech and Hearing Research, 34, 60-66.

De Nil, L. F., \& Kroll, R. M. (1995). The relationship between locus of control and long-term stuttering treatment outcome in adult stutterers. Journal of Fluency Disorders, 20, 345-364.

DeCharms, R. (1968). Personal causation: the internal affective determinants of behavior. New York, NY: Academic Press.

Gottschalk, L. A., \& Gleser, G. C. (1969). The measurement of psychological states through the content analysis of verbal behavior. Berkeley, CA: University of California Press.

Guitar, B. (2014). Stuttering: an integrated approach to its nature and treatment (4th ed.). Philadelphia, PA: Lippincott Williams \& Wilkins.

Hugh-Jones, S., \& Smith, P. K. (1999). Self-reports of short- and long-term effects of bullying on children who stammer. British Journal of Educational 
Psychology, 69, 141-158.

Kim, S. (2008). A study on gender differences of gender-role stereotype among youth. Korean Journal of Social Welfare Studies, 36, 129-149.

Lee, H., Lee, S., Sim, H., \& Oh, I. (2016). A qualitative study of exploring bullying experiences of adolescents who stutter. The Elementary School Journal, 64, 417-450.

Lee, K. (2013). Locus of causality differences in the writings of university students according to gender and topic of writing. Communication Sciences \& Disorders, 18, 116-126.

Lee, K. (2017). Communication locus of causality measures for adolescents who stutter: a preliminary study. Communication Sciences \& Disorders, 22, 352-363.

Lee, K., Manning, W. H., \& Herder, C. (2011). Documenting changes in adult speakers' locus of causality during stuttering treatment using origin and pawn scaling. Journal of Fluency Disorders, 36, 231-245.

Lee, K., Manning, W. H., \& Herder, C. (2015). Origin and Pawn scaling for adults who do and do not stutter: a preliminary comparison. Journal of Fluency Disorders, 45, 73-81.

Manning, W. H. (2010). Clinical decision making in fluency disorders (3rd ed.). Clifton Park, NY: Delmar/Cengage Learning.

McAllister, J., Collier, J., \& Shepstone, L. (2012). The impact of adolescent stuttering on educational and employment outcomes: evidence from a birth cohort study. Journal of Fluency Disorders, 37, 106-121.
O’Brian, S., Jones, M., Packman, A., Menzies, R., \& Onslow, M. (2011). Stuttering severity and educational attainment. Journal of Fluency Disorders, 36, 86-92.

Shin, M., \& Lee, K. (2014). Communication-related and general locus of causality of male adults who stutter. Communication Sciences \& Disorders, 19, 238-248.

Shin, M., Lee, K., \& Sung, J. (2015). Locus of causality comparison of male adults who do and do not stutter. Communication Sciences \& Disorders, 20, 596-606.

Silverman, E. M. (1980). Communication attitudes of women who stutter. Journal of Speech and Hearing Disorders, 45, 533-539.

Sim, H. S., Shin, M. J., \& Lee, E. J. (2010). Paradise-Fluency Assessment-II. Seoul: Paradise Welfare Foundation.

Vanryckeghem, M., Brutten, G. J., \& Hernandez, L. M. (2005). A comparative investigation of the speech-associated attitude of preschool and kindergarten children who do and do not stutter. Journal of Fluency Disorders, 30, 307-318.

Westbrook, M. T., \& Viney, L. L. (1980). Scales measuring people’s perception of themselves as origins and pawns. Journal of Personality Assessment, 44, 167-174.

Williams, D. E., Melrose, B. M., \& Woods, C. L. (1969). The relationship between stuttering and academic achievement in children. Journal of Communication Disorders, 2, 87-98. 


\section{국문초록}

\section{의사소통 인과소 평가도구로 측정한 성과 연령에 따른 일반청소년의 인과소 차이 이경재}

대구가톨릭대학교 언어청각치료학과

배경 및 목적: 최근 말더듬청소년을 대상으로 인과소를 살펴보기 위한 설문지 형식의 평가도구가 제시되었으나 이를 이용하여 측정한 청소년의 의사소통 관련 인과소 연구는 부족한 편이다. 의사소통 관련 인과소는 치료 중 변화의 지표가 될 수 있기에 본 연구는 말더듬 청소년의 평가와 중재와 관련된 임상적인 자료를 제공하기 위하여 설문지 형식으로 된 의사소통 관련 인과소 평가도구 결과가 연령(중 학교와 고등학교)과 성에 따른 차이를 보이는지 살펴보고자 하였다. 더불어 내용분석을 이용한 인과소, 행동통제소검사, 의사소통태 도검사 등과 같은 다른 평가도구와의 비교를 통하여 설문지 형식의 인과소 평가도구의 타당도를 살펴보고자 하였다. 방법: 본 연구에는 총 40 명의 일반청소년이 참여하였다. 이들을 대상으로 설문지 형식의 의사소통 인과소 평가도구를 사용하여 오리진과 폰을 측정하였 다. 또한 내용분석을 사용하여 의사소통 관련 인과소와 일반적인 인과소를 측정하였다. 더불어 행동통제소검사와 파라다이스-유창성 검사-II의 의사소통태도검사를 실시하였다. 결과: 성별과 연령에 따라 의사소통 인과소 평가도구 결과는 통계적으로 유의한 차이를 보 이지 않았으나 효과크기가 중간 정도인 경우가 관찰되었다. 다른 평가도구에서도 성별과 연령에 따른 차이가 통계적으로 유의하지는 않았으나 중간 정도 크기의 효과크기를 보인 경우도 관찰되었다. 더불어 의사소통 인과소 평가도구는 다른 평가도구와 유의한 상관관 계를 보였다. 논의 및 결론: 본 연구는 의사소통 인과소 평가도구가 타당한 평가도구라는 점을 다시 한 번 강조한다. 비록 통계적으로 유의한 차이는 아니지만 중간 정도 크기의 효과크기가 관찰되었기에 이후 임상에서 말더듬청소년을 대상으로 평가와 중재를 진행할 경우 이와같은 성과 연령에 따른 차이를 고려하여야 할 것이다.

핵심어: 말더듬, 청소년, 오리진, 폰, 인과소

본 연구는 2015년 대한민국 교육부와한국연구재단의 지원을 받아수행된 연구임(No. NRF-2015S1A5A8017349).

\section{참고문헌}

김소정(2008). 청소년 성역할 고정관념에 관한 연구: 성 차이를 중심으로. 사회복지연구, 36, 129-149.

신문자, 이경재(2014). 말더듬성인남성의 의사소통 상황과 일반적인 상황 관련 글쓰기에서의 인과소 비교. 언어청각장애연구, 19, 238-248.

신문자, 이경재, 성진아(2015). 말더듬성인 남성과 일반성인 남성의 인과소 비교. 언어청각장애연구, 20, 596-606.

심현섭, 신문자, 이은주(2010). 파라다이스-유창성 검사II. 서울: 파라다이스 복지재단.

이경재(2013). 일반 대학생의 글쓰기 분석을 통한 성별과 주제에 따른 인과소차이. 언어청각장애연구, 18, 116-126.

이경재(2017). 말더듬청소년을 대상으로 한 의사소통 관련 인과소 평가도구 기초 연구. 언어청각장애연구, 22, 352-363.

이현경, 이수복, 심현섭, 오인수(2016). 말더듬 청소년의 괴롭힘(bullying)에 관한 질적연구. 중등교육연구, 64, 417-450. 